\title{
PHOTOMETRY OF STARS FOR ASTRONEGATIVES WITH A SINGLE EXPOSURE
}

\author{
V. Andruk ${ }^{1}$, I. Eglitis ${ }^{2}$, Yu. Protsyuk ${ }^{3}$, V. Akhmetov ${ }^{4}$, L. Pakuliak ${ }^{1}$, \\ S. Shatokhina ${ }^{1}$, O. Yizhakevych ${ }^{1}$ \\ ${ }^{1}$ Main Astronomical Observatory of National Academy of Sciences, \\ 27 Akad. Zabolotnogo St., 03143 Kyiv, Ukraine, andruk@mao.kiev.ua \\ 2 Institute of Astronomy, University of Latvia, \\ Boulv. Rainis 19. LV-1586 Riga Latvia, ilgmars.eglitis@lu.lv \\ ${ }^{3}$ Research Institute Mykolaiv Astronomical Observatory, \\ 1 Observatorna Str., 54000 Mykolaiv, Ukraine, yuri@nao.nikolaev.ua \\ ${ }^{4}$ Institute of Astronomy of V. N. Karazin KNU, \\ 4 Svobody Sq., 61022 Ukraine Kharkiv, Ukraine, akhmetovvs@gmail.com
}

\begin{abstract}
The paper discusses the construction of characteristic curves for various astronegatives with a single exposure. Particular attention is paid to the question of extrapolation of the characteristic curve for the region of the weakest stars in the absence of standards. A new method for constructing an individual characteristic curve for digitized films and plates in the UBVR system has been proposed and implemented. The processing of frames of digitized plates and films with sky areas is carried out using LINUX/MIDAS/ROMAFOT software tools. ROMAFOT application allows us to extract astrometric rectangular coordinates $\mathrm{X}, \mathrm{Y}$ and photometric characteristics such as instrumental photometric magnitudes $\mathrm{m}, \mathrm{FWHM}$, and the intensity in the center of the star image $I_{c}$ for all fixed objects on each astronegative. For all frames, the connection between instrumental photometric values $m$ with stellar magnitudes in any system (Johnson UBVR, Tycho-2 or GAIA catalogs, etc.) is not linear and multipurpose. It is presented as the characteristic curve for each astronegative. In general, the characteristic curve is approximated by a 5-degree polynomial and should take into account the color equation and the photometric field error. In practice, the most and the sometimes unsolvable problem is the lack of photometric standards for the flat part of the characteristic curve (the region of faint and extremely faint stars). As a rule, the photometric standards for characteristic curve restoration from astronegatives, exposed in Johnson U, B, V or R bands (hereafter U, B, V, $\mathrm{R}$ ), are photoelectric data of stars in the same system. The present work concentrates on the issue of a correct definition of stellar U, B, V, R magnitudes from astronegatives obtained with a single exposition in the case when photometric standards are absent for the flat part of the characteristic curve. Currently, the determination of $\mathrm{U}, \mathrm{B}, \mathrm{V}, \mathrm{R}$ magnitudes of stars and other space objects is in progress for astronegatives with the single exposure obtained in the frameworks of selected observational projects.
\end{abstract}

Keywords: stellar catalogs, digitized plate processing, photometry, UBV system.
АНОТАЦІЯ. В статті обговорюються питання побудови характеристичних кривих для астронегативів 3 однією експозицією. Особливу увагу приділено питанню екстраполяції характеристичної кривої на ділянку найслабкішіх зір за відсутності фотометричних стандартів. Запропонований новий метод побудови індивідуальної характеристичної кривої для оцифрованих плівок і пластинок, отриманих в UBVR системі. Метод використаний в низці спостережних проектів. Обробка кадрів для оцифрованих платівок і плівок з зображеннями ділянок зоряного неба робиться в програмному середовищі LINUX/MIDAS/ROMAFOT. Вакористання пакета програм ROMAFOT дозволяє отримувати астрометричні (прямокутні координати X,Y) та фотометричні характеристики (інструментальні фотометричні величини $\mathrm{m}$, FWHM, інтенсивність в центрі зображення Ic) для всіх зареєстрованих на конкретному астронегативі об'єктів. Для астронегативів (платівки, плівки) зв'язок інструментальних фотометричних величин $\mathrm{m}$ з зоряними величинами в якійсь системі (наприклад UBVR Джонсона, каталогів Тусhо-2, Gaia DR2 тощо) не є лінійною та універсальною і задається в вигляді характеристичної кривої для конкретного астронегатива. В загальному випадку характеристична крива апроксимується поліномом п'ятої степені і повинна враховувати рівняння кольору та фотометричну похибку поля. На практиці великою і інколи не варішуваною проблемою $є$ відсутність фотометричних стандартів для пологої частини характеристичної кривої (область слабких і гранично слабких зір). Як правило, фотометричними стандартами для побудови характеристичних кривих для астронегативів, експонованих в U, B, V чи R смугах системи Джонсона є фотоелектричні виміри зір в цій же ж системі. Питанню коректного визначення зоряних $\mathrm{U}, \mathrm{B}, \mathrm{V}, \mathrm{R}$ величин для астронегативів 3 однією експозицією за відсутності фотометричних стандартів для пологої частини характеристичної кривої і присвячена дана робота. На даний час виконуються роботи по визначенню $\mathrm{U}, \mathrm{B}, \mathrm{V}, \mathrm{R}$ величин зір та інших об'єктів для астронегативів, експонованих 3 
однією експозицією за вибраними спостережними програмами з різних обсерваторій.

Ключові слова: зоряні каталоги, обробка оцифрованих зображень, фотометрія, система UBV.

\section{Introduction}

The processing of frames for digitized plates and films with sky areas in the software package LINUX/MIDAS/ROMAFOT. The application of ROMAFOT allows obtaining the astrometric (rectangular coordinates $\mathrm{X}, \mathrm{Y}$ ) and photometric characteristics (instrumental photometric magnitudes m, FWHM, intensities in the center of the image Ic) for all registered objects on the individual astronegative. As a rule, for faint objects, the limit of their formation and registration is set by the relation signal/noise $s>3$. The related problems and their solutions have been considered in (Andruk, 2010; Andruk, 2017). For astronegatives (plates, films), the relation between instrumental photometric magnitudes $\mathbf{m}$ and stellar magnitudes in some photometric system (for example, Johnson UBVR, Tycho-2, Gaia DR2 catalogs, etc) is not linear. It is set as a characteristic curve for every negative.

In general, the characteristic curve is approximated by a 5-degree polynomial and should take into account the color equation and the photometric field error. In practice, the most and the sometimes unsolvable problem is the lack of photometric standards for the flat part of the characteristic curve (the region of faint and extremely faint stars). As a rule, the photometric standards for characteristic curve restoration from astronegatives, exposed in Johnson U, B, V or $\mathrm{R}$ bands (hereafter $\mathrm{U}, \mathrm{B}, \mathrm{V}, \mathrm{R}$ ), are photoelectric data of stars in the same system (Relke, 2015). If the negative was obtained with two exposures - long and short ones (Andruk, 2012), the problem of the whole characteristic curve restoration is simplified and successfully solved in practice as it was done when FON project had been realizing (Akhmetov, 2018; Andruk, 2015; Andruk, 2016a; Andruk, 2016b; Andruk, 2017; Pakuliak, 2016; Yuldoshev, 2016; Yuldoshev, 2017a; Yuldoshev, 2017b) or for other programs as it presented in (Protsyuk, 2017; Yizhakevych, 2015; Yizhakevych, 2017; Shatokhina, 2018).

The present work concentrates on the issue of a correct definition of stellar U, B, V, R magnitudes from astronegatives obtained with a single exposition in the case when photometric standards are absent for the flat part of the characteristic curve..

\section{Plotting of the empirical characteristic curve from astronegatives with a single exposure}

For creating an empirical characteristic curve, we used two plates №1834 and №1809 from the glass collection of the 1.2-m Schmidt telescope of the Baldone Observatory, Latvia. Plates have the exposures 40 and 60 minutes in $U$ color band (ORWO ZU2 emulsion with UG1 filter) (Eglite, 2016). The digitizing of astronegatives was carried out using the Epson Expression 10000XL commercial scanner (Eglitis, 2017). Plates cover the sky area with NGC 7419 cluster $\left(\mathrm{RA}=23^{\mathrm{h}} 01^{\mathrm{m}} 30^{\mathrm{m}}, \mathrm{DEC}=60^{\circ} 32^{\prime}\right)$.
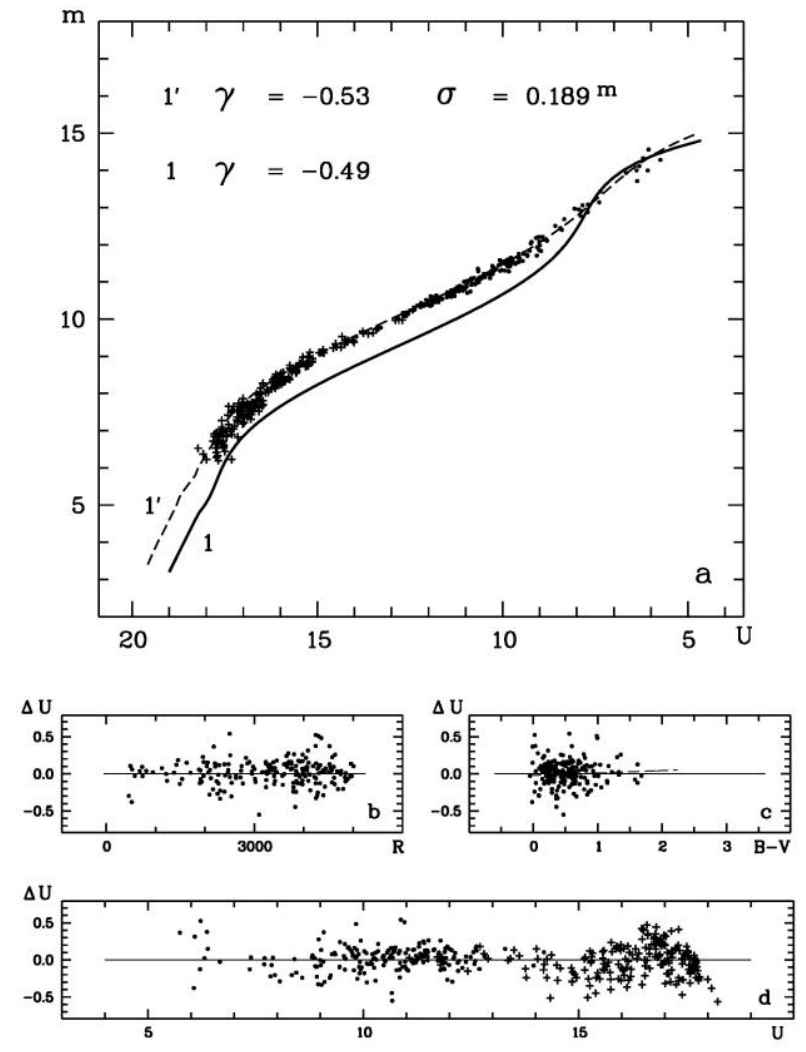

Figure 1: Characteristic curves for plates №1834 (1') и №1809 (1), exposed in U color on 1.2-m Schmidt telescope at Baldone (a-panel). Panels $\mathbf{b}, \mathbf{c}$ and $\mathbf{d}$ contain sections of characteristic curve 1' vs a distance to the center of the plate, relative to a color index $\mathrm{B}-\mathrm{V}$, and vs $\mathrm{U}$ magnitudes respectively. Points and crosses on the plot correspond to photoelectric and CCD measurements of star images.

The upper panel a of Fig. 1 presents next data: $U$ scale is along the $\mathrm{X}$-axis, the instrumental scale is along the $\mathrm{Y}$-axis, points and crosses are the stars with photoelectric and CCD measurements respectively. The linear part of the characteristic curve 1' from the astronegative №1834 covers the interval $\mathrm{U}=10-15^{\mathrm{m}}$ and characterizes the image contrast of $\gamma=-0.53$, the dispersion of points is $\sigma_{U}=0.189^{\mathrm{m}}$.

On the flat part of the characteristic curve (from $U>$ $15^{\mathrm{m}}$ to $\mathrm{U}<18^{\mathrm{m}}$ ), all the faint and extremely faint stars down to $\mathrm{U}=18^{\mathrm{m}}$ are fixed, which were used as a standard for the restoration of the curve. Dashed line (below $\mathrm{m}<$ $6^{\mathrm{m}}$ ) is the region of the extrapolation. Panels b, c, $\mathbf{d}$ in Fig. 1 show the section of the characteristic curve $\Delta U$ in relation to the distance from the center of the plate $\mathrm{R}$, color index $\mathrm{B}-\mathrm{V}$, and $\mathrm{U}$ magnitude itself. On the right and below the first curve 1' there is the characteristic curve $\mathbf{1}$ of the astronegative №1809 $(\gamma=-0.49)$. Further, we use the tabular representation of this curve for the restoration of individual curves from other negatives.

\section{An example of the individual characteristic curve restoration}

The characteristic curve of the shape $\mathbf{1}$ in Fig. 1 was restored from the astronegative exposed in U-band. It is characterized by a contrast ratio of $\gamma=-0.49$. In general, if 

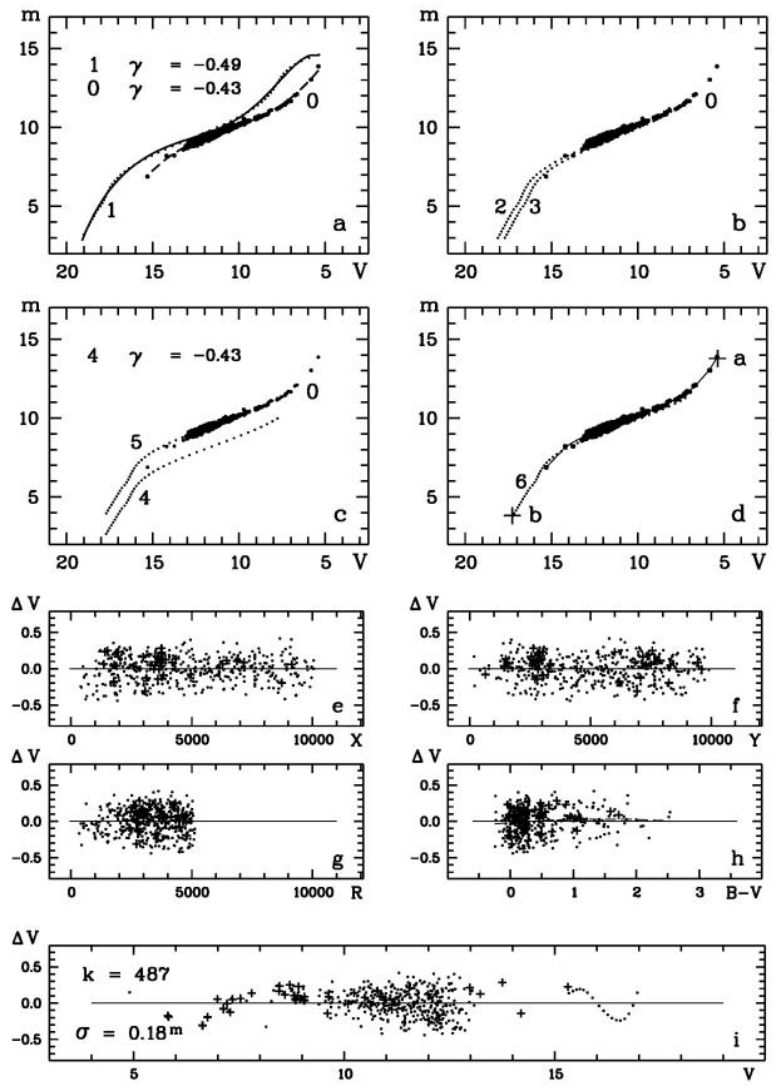

Figure 2: Steps of the extraction of a characteristic curve from the film №624 exposed in the V-color on the 1.2-m Schmidt telescope at Baldone.

the astronegative is not spoiled by a flare and other deteriorating factors, the value of the ratio depends on the exposition duration and the sensitivity of the photo emulsion. That is, the shape of the curve $\mathbf{1}$ will vary for other emulsions and/or exposures of other duration, and in the procedure of curve restoration from other negatives, the important task is the possibility and necessity of changing the contrast from the original value of $\gamma=-0.49$ to the real one for a particular image.

Consider the extraction of the characteristic curve for the film exposed in the V-band (Fig. 2). Here, V magnitudes are along the $\mathrm{X}$-axis, photometric magnitudes $\mathbf{m}$ in the instrumental system are along the Y-axis. Panel a in Fig. 2 demonstrates next: a solid line $\mathbf{1}$ represents the empirical curve for U-plate №1809, the sequence of points $\mathbf{0}$ is a part of the real characteristic curve for the film (A600 film, ZS17 filter ) with the flat part absent in the region of underexposure. The film was obtained on 1.2-m Schmidt telescope with 5-minute exposure and the cluster NGC 7063 $\left(\mathrm{RA}=21^{\mathrm{h}} 27^{\mathrm{m}}, \mathrm{DEC}=37^{\circ} 42^{\prime}\right)$ as the object of interest. The real characteristic curve $\mathbf{0}$ has a contrast ratio of $\gamma=-0.43$.

To extract the characteristic curve throughout its length from bright to extremely faint stars registered on the film, first, we cut the empirical curve 1 (b-panel, Fig. 2) in the region of bright stars and shift it by two steps (curves $\mathbf{2}$ and 3, Fig. 2) to the right. Then, the contrast of the empirical curve $(\gamma=-0.49)$ is reduced to the contrast of the film $(\gamma=$ -0.43 ). In the figure, it is represented by the curve 4 . Then
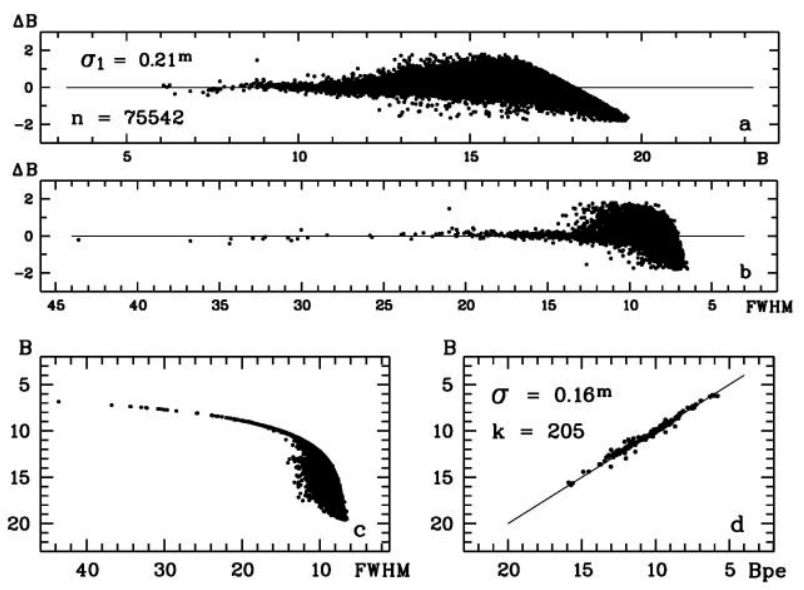

Figure 3: The assessment of the accuracy of determined stellar magnitudes for two plates with 20-minutes exposures in B-color on 1.2-m Schmidt telescope.

this line is shifted vertically to the curve $\mathbf{5}$ shown in c-panel of the figure. The shift of the curve $\mathbf{5}$ to the right is the last step for the restoration of the complete characteristic curve, which is the sum of curves $\mathbf{0}$ and 6. The complete curve, restored from the film №624 obtained in V band is shown in d-panel of Fig. 2. In this panel, crosses $\mathbf{a}$ and $\mathbf{b}$ indicates the limiting values of instrumental photometric data for bright and faint objects fixed on this film.

When restoring the curve from the film, we used both photoelectric measurements from the catalog (Relke, 2015) (panels e, f, g, h, i, crosses) and values $\mathrm{Vj}$ from the catalog Tycho-2 (points in the same panels). The standard error of curve restoration $\sigma=0.18^{\mathrm{m}}$ is shown in the panel $\mathbf{i}$ of Fig. 2. It should be noted that all the shifts of the empirical curve 1 and the changings in its contrast relative to the real characteristic curve of the film were made based on the comparative analysis of linear parts of both curves using data on lower left points of the real characteristic curve. The algorithm for constructing the individual characteristic curve and determining U, B, V or R stellar magnitudes on its basis for all objects registered on the astronegative allows these processes to be started in automatic mode using the specially developed software.

\section{About the errors of stellar magnitude determination.}

We evaluated the accuracy of determined stellar magnitudes in a case of using the empirical characteristic curve on the example of two plates obtained with exposure 20 minutes in B color band on 1.2-m Schmidt telescope. Plates were obtained on two different nights with different observing conditions. Both plates are covered with the emulsion ORWO ZU2, the filter used was GG13. The sky area covered with plates is the region of NGC 1664 cluster $\left(\mathrm{RA}=04^{\mathrm{h}} 50^{\mathrm{m}}, \mathrm{DEC}=42^{\circ} 27^{\prime}\right)$.

After the determination of stellar magnitudes for all registered objects on two plates, the number of identified stars on both plates was $\mathbf{n}=75542$. For all of them, the differences of stellar magnitudes $\Delta \mathrm{B}$ were calculated, and the standard error of one difference was obtained $\boldsymbol{\sigma}_{\mathbf{1}}=$ $0.21^{\mathrm{m}}$. The trends of differences $\mathbf{\Delta B}$ relative to stellar 
magnitude $\mathbf{B}$ and values of FWHM are represented in panels $\mathbf{a}$ and $\mathbf{b}$ of Fig. 3. The c-panel of the figure shows the connection of values B and FWHM averaged over two plates. The d-panel demonstrates the linear connection between calculated mean values of $\mathbf{B}$ with a standard errors of one measure $\boldsymbol{\sigma}=0.16^{\mathrm{m}}$ and their photoelectric counterparts $\mathbf{B}_{\text {pe }}$ for $\mathrm{k}=205$ stars.

\section{Conclusions}

The method outlined in this paper on the determination of $\mathrm{U}, \mathrm{B}, \mathrm{V}$ stellar magnitudes from astronegatives with a single exposure is already widely applied in practice. In particular, it was used for the determination of $\mathrm{B}$ magnitudes for 387 plates obtained on the fourth tube of 7-camera telescope of Odessa observatory at Mayaki observational site during 1966-1998 (Kashuba, 2019). It was also applied for the determination of $\mathrm{U}$ and $\mathrm{V}$ magnitudes of stars from 300 plates and 2200 films exposed on $1.2 \mathrm{~m}$ Schmidt telescope at Baldone observatory (Eglitis, 2019). Analogous works on the determination of $\mathrm{U}, \mathrm{B}, \mathrm{V}, \mathrm{R}$ stellar magnitudes in frameworks of some current observational projects at different observatories are in their progress.

The work was carried out as a part of the Ukrainian Virtual Observatory (UkrVO) project. (Vavilova, 2012a; Vavilova, 2012b; Vavilova, 2016; Vavilova, 2017).

\section{References}

Akhmetov V.S., Khlamov S.V., Andruk V.M., Protsyuk Yu.I.: 2018, Odessa Astron Publ., 31, 199.

Andruk V.M., Butenko G.Z., Yatsenko A.I.: 2010, Kinem. Phys. Cel. Bodies, 26, N3, 146.

Andruk V.M., Ivanov G.A., Yatsenko A.I. et al.: 2012, BTSNU, N48, 11.

Andruk V.M., Pakuliak L.K., Golovnia V.V. et al.: 2015, Odessa Astron. Publ., 28, 192.
Andruk V.M., Golovnia V.V., Ivanov G.A. et al.: 2016, Kinem. Phys. Cel. Bodies, 32, N1, 32.

Andruk V.M., Pakuliak L.K., Golovnia V.V. et al.: 2016, Kinem. Phys. Cel. Bodies, 32, N5, 260.

Andruk V., Yuldoshev Q., Eglitis I. et al.: 2017, Odessa Astron. Publ., 30, 159.

Andruk V.M., Pakuliak L.K., Golovnia V.V. et al.: 2017, Science and Innovation, 13, N1, 17.

Eglite M., Eglitis I.: 2016, Odessa Astron. Publ., 29, 120.

Eglitis I., Andruk V. : 2017, Open Astronomy, 26, N1, 7.

Eglitis I., Shatokhina S., Yizhakevych O. et al.: 2019, Odessa Astron. Publ., 32, In press.

Kashuba S., Kashuba V., Andruk V.: 2019, Odessa Astron. Publ., 32, In press.

Pakuliak L.K., Andruk V.M., Golovnia V.V. et al.: 2016, Odessa Astron. Publ., 29, 132.

Protsyuk Yu.I., Kovylianska O.E., Protsyuk S.V., Yizhakevych O.M. et al.: 2017, Science\&Innovation, 13, N1, 89.

Relke E., Protsyuk Yu.I., Andruk V.M.: 2015, Odessa Astron. Publ., 28, 211.

Shatokhina S.V., Kazantseva L.V., Yizhakevych O.M., Andruk V.M.: 2018, Kinem. Phys. Cel. Bodies, 34, N5, 270.

Vavilova I.B., Pakulyak L.K., Shlyapnikov A.A. et al.: 2012, Kinem. Phys. Cel. Bodies, 28, N4, 85.

Vavilova I.B., Pakuliak L.K., Protsyuk Yu.I. et al.: 2012, Baltic Ast., 21, N3, 356.

Vavilova I.B.: 2016, Odessa Astron. Publ., 29, 109.

Vavilova I.B., Yatskiv Ya.S., Pakuliak L.K.: 2017, IAUS, 325, 361.

Yizhakevych O.M., Andruk V.M., Pakuliak L.K.: 2015, Odessa Astron. Publ., 28, 213.

Yizhakevych O.M., Andruk V.M., Pakuliak L.K.: 2017, Kinem. Phys. Cel. Bodies, 33, N3, 142.

Yuldoshev Q.X., Muminov M.M., Ehgamberdiev Sh.A. et al.: 2016, Odessa Astron. Publ., 29, 160.

Yuldoshev Q.X., Muminov M.M., Ehgamberdiev Sh.A. et al.: 2017, Odessa Astron. Publ., 30, 205. 